\title{
The taboos attached to the translation of biological terms from English into Northern Sotho
}

\author{
D.R. Mabule \\ Department of Linguistics, University of South Africa \\ P.O. Box 392, UNISA 0003, Pretoria, South Africa \\ mabuldr@unisa.ac.za
}

\begin{abstract}
The aim of this article is to investigate the taboos attached to the translation of biological science terms into Northern Sotho, a language whose scientific register is not as developed as that of English. It is expected of the translator to translate the terms in such a way that the readership for whom the translation is intended will not feel offended by the terms used. This however, sometimes poses problems since the use of certain biological terms may be seen as undermining the cultural values and norms of Northern Sotho speaking people. To highlight the problems as perceived in relation to the use of biological terms, human physiological terms, when translated into Northern Sotho, will be discussed.
\end{abstract}

\section{Introduction}

When the eleven official languages were entrenched into the new Constitution of South Africa in 1996, the language status of African languages was elevated to the level of English and Afrikaans. This means that the African languages are also acknowledged as official languages. Multilingualism is the key to solving the problems involved in the teaching of biological science where code-switching or translation plays an important role in achieving the end result that would be beneficial to both learners and teachers.

This article will investigate the taboos attached to the translation of biological science terms into Northern Sotho, a language whose scientific register is not as developed as that of English. Translating physiological terms into Northern Sotho may be complicated by cultural barriers that could hamper the process of translation due to the fact that the targeted readership might feel undermined by the translated terms that go against the cultural norms and values.

There is a generally accepted tendency among translators to insist on culture-bound terminology. In Northern Sotho, this involves more use of figurative rather than literal language as, for example, when the translation incorporates the physiological anatomy of a human being, particularly the functions of such parts. The problem that arises, according to Alberts (1997), is not that there are no equivalents but rather that the terminological issues come into play.

Some words have limited domains and may not be used by polite people unless they breach the rules of good manners. Wardhaugh (1992:234) agrees with Alberts by developing this argument and saying that certain things are not mentioned, not because they cannot be said, but because 'people don't talk about those things; or if those things are talked about, they are talked about in very roundabout ways'. Translators and interpreters, therefore, employ euphemisms to avoid mentioning certain issues directly.

Wardhaugh (1992) goes as far as to say that certain things or parts can be referred to only in particular circumstances, for example, only by some people, or through deliberate circumlocutions. Awareness of the target reader forces the translator to constantly resort to circumlocutions and euphemisms to avoid the direct mention of taboo matters, particularly pertaining to parts of the body and their functions. The option of metaphorical language is perceived by the public to be an appropriate way to avoid offending the targeted reader, but it hampers the transmission of the correct message, especially in the translation and development of scientific terms. 
To explain why it can be regarded as taboo to translate human anatomy terms, especially those that relate to reproduction, I shall define the terms that are relevant to this investigation. The following terms will be defined: 'culture', 'culturalism', 'cultural-sensitive concepts', 'euphemistic'/'metaphorical expressions' and 'taboo'.

\section{Culture}

The term 'culture' invokes a range of issues and is sometimes misinterpreted by a majority of people as well as some scholars in the field. According to Fowler (1993:51), 'Culture in this sense implies the accumulation of discriminations. It implies a selective social structure, since it distinguishes passive recipients of social perspectives from those who cultivate an awareness of such perspective ...' In this context, the term is used in the conventional sense of social culture and this article deals with culture as "the way of life and its manifestations that are peculiar to a community that uses a particular language as its means of expression' (Newmark, 1988:94).

Wardhaugh (1992:217) uses 'culture' in the sense of whatever a person must know in order to function in a particular society. Culture is, therefore, the 'know-how' that a person must possess to get through the task of daily living. It can be said that culture is a set of assumptions, beliefs and attitudes that people build up over a period of time. The assumptions, beliefs and attitudes differ from one culture to another - in this case, from the perspective of a translator.

There is a relationship between language and culture. This can be traced back to the linguist Edward Sapir and his student, Benjamin Lee Whorf. The Whorfian hypothesis clearly shows the relationship between language and culture, maintaining that they are inextricably related to such an extent that one cannot understand or appreciate one without the other. He says that human beings do not live in the objective world alone or in the world of social activity as ordinarily understood, but are at the mercy of a particular language which has become the medium of expression for the society. It is quite an illusion to imagine that one adjusts to reality essentially without the use of language and that language is merely an incidental means of solving specific problems of communication or reflection (Wardhaugh, 1992:218-219).

Goodenough (1964:39) also pursues this line of thinking. Despite the dated reference, what he has to say is still relevant today. Goodenough is convinced that language plays an overwhelming role in culture and the way it is learned. He states that 'it is in the course of learning his language and how to use it that every human being acquires the bulk of his culture'. Every language is, therefore, a symbol of the culture with which it is most intimately associated. These views are compatible with those of Nida (1964:148), who claims that a text is embedded in a given situation, which is in itself conditioned by its socio-cultural background. He questions the wisdom of the translator who tries to escape from his/her own cultural context.

Wilss (1996:85) insists that language and culture are intrinsically intertwined. He believes that language is embedded in culture and vice versa. He further argues that language is as much a cultural product as culture is a linguistic product. This view is supported by Bassnett-McGuire (1980:39) who emphatically states that 'No language can exist unless it is steeped in the context of culture, and no culture can exist which does not have at its center the structure of natural language'. Language, then, is the heart within the body of culture and it is the interaction between the two that results in the continuation of life energy. Therefore, the translator cannot treat the text in isolation from its culture.

\section{Culturalism}

This term is derived from the term 'culture', which refers to the sum total ways of living built up by a group of people, and handed down from one generation to the next. In the broadest sense, 'culturalism' can be understood as the established ways of sharing and regulating experience. Communities and groups evolve through common 
forms of expression, of which means of approaches of the traditional values and norms are advocated. From a linguistic perspective, the term could be defined as a doctrine that promotes and preserves traditional forms of communicative interaction. In this context, this means that the translator will have to compromise on the use of equivalent terms in favour of metaphorical expressions for the translation to be accepted.

\section{Culturally sensitive terms}

In this article, 'culturally sensitive' refers to those equivalent terms in the target language that are not easily mentioned, as they are perceived as being taboo or offensive. In most cases, these terms are associated with reproduction; for example, the naming and the functions of organs of human reproduction are perceived as taboo in Northern Sotho and, therefore, the use of euphemisms functions prominently for the translated text to be acceptable to the targeted readers.

\section{Euphemistic/metaphorical expressions}

Contextually, these refer to figures of speech whereby speakers speak about one thing in terms that are seen as suggestive of another. According to Nida (1964), these expressions are used in place of another meaning or expression which is not synonymous but has an associated idea often mediated through supplementary components. This could be defined best as the dressing up of a language in certain areas of life to make it look presentable and culturally acceptable (Wardhaugh, 1992:236). These expressions concur with Newmark's (1988:84) remarks that these expressions are merely being used for the purpose of 'colouring' language rather than sharpening it to describe the life of the world or mind more accurately. In this article, it means that the direct use of biological terms is shielded by the use of metaphorical expressions as substitutions for words that are regarded as taboo. The use of euphemistic expressions enables the translator to transmit the message although some information of the source text, in this instance biological terms, is distorted.

\section{Taboo}

Fromkin and Rodman (1993:303) posed questions on the 'filthiness' and 'cleanliness' of a language. They said that the filth or the beauty of a language must be in the ear of the listener, or in the collective ear of society. Clearly, one can say that certain words in all societies are considered taboo. "The word "taboo" was borrowed from Tongan, a Polynesian language, and refers to acts that are forbidden or to be avoided' (Fromkin \& Rodman, 1993:303). Taboo is, in most cases, a ritual restriction or prohibition. According to Wardhaugh (1992:236), '[t]aboo is one way in which a society expresses its disapproval of certain kinds of behavior believed to be harmful to its members, either for supernatural reasons or because such behavior is held to violate a moral code'. Tabooed subjects can vary widely: sex, death, excretion, bodily functions, religious matters and politics. Words that are related to sex, sexual organs and bodily functions make up a large part of the set of taboo words in many cultures. According to Fromkin and Rodman (1993:304), 'the existence of taboo words or taboo ideas stimulates the creation of euphemisms'.

In Northern Sotho, there is a word that means 'sexual intercourse' but the use of this word nyobana is forbidden and instead, the euphemistic word thobalano, is used. The word thobalano may have a meaning that is different from 'sexual intercourse', as it does not clearly indicate penetration of the penis into the vagina. It can mean sleeping on top of one another but not necessarily having sexual intercourse. Taboo words are, in most instances, being replaced by ordinary euphemistic expressions in the translation of certain sensitive documents to avoid unpleasant subjects. In most instances, the targeted reader feels offended when a translator uses direct equivalents of certain tabooed words, especially when translating bodily functions of organs of human reproduction. The reader will label such translators as vulgar and insensitive to the culture, norms and values of the target readers.

Hermans (1996:33) made the modalities of normative force as follows: 
Figure 1: Modalities of normative force

\begin{tabular}{|l}
$\begin{array}{c}\text { OBLIGATION } \\
\text { (what is prescribed) }\end{array}$ \\
$\begin{array}{l}\text { NON-PROHIBITION } \\
\text { (what is not forbidden, } \\
\text { i.e. what is tolerated) }\end{array}$
\end{tabular}

Discussing this diagram, Hermans (1996:32) says 'Norms and rules may cover a narrow or a broad domain. They may or may not be explicitly posited'. He continues to say that the modalities of normative force in this diagram indicate the relative strength of a norm, together with its positive or negative load. He explains that modality may be negative or positive towards obligations or towards prohibitions. In translation, the translator should learn to operate the norms of translation, which means he/she should operate with them and within them (Hermans, 1996:32-34).

\section{Problem of translating biological terms seen as taboo in Northern Sotho}

For one to understand the problems involved in the translation of words for organs of reproduction into Northern Sotho, one has to discuss what translation is and its processes. According to Newmark (1988:19), translation procedures are operational, and translation requires a translator to have four levels more or less consciously in mind.

These levels are as follows:

- The source language text level, which is the level of language where one begins and which one continually refers back to.

- The referential level, which is the level of objects and events, real or imaginary, which one has to progressively visualize and build up, and which is an essential part, first of comprehension, then of the reproduction process.

- The cohesive level, which is more general, and grammatical, which traces the train of thought, the feeling, tone (positive or negative) and the various propositions of the source language text. This level gives an overall picture to which one may adjust the language level.

- The level of naturalness, of common language appropriate to the writer or the speaker in a certain situation. This level also is a generalized level of a band within which the translator works, unless the text to be translated is an authoritative text.

\section{Relation of translating to translation theory}

Translation is a complex system that involves communication across a variety of cultural and linguistic levels. Newmark (1988:19) states that:

\footnotetext{
the purpose of this theory of translating is to be of service to the translator. It is designed to be a continuous link between translation theory and practice; it derives from a translation theory framework which proposes that when the main purpose of the text is to convey information and convince reader (sic), a method of translation must be 'natural'.
}

He continues to say that the level of naturalness binds the translation theory to the translating theory, and translating theory to practice. He argues that if one accepts this theory of translation, there will be no gaps between the translation theory and practice. 
Figure 2: Newmark's schematic representation of a functional theory of language (1988:20)

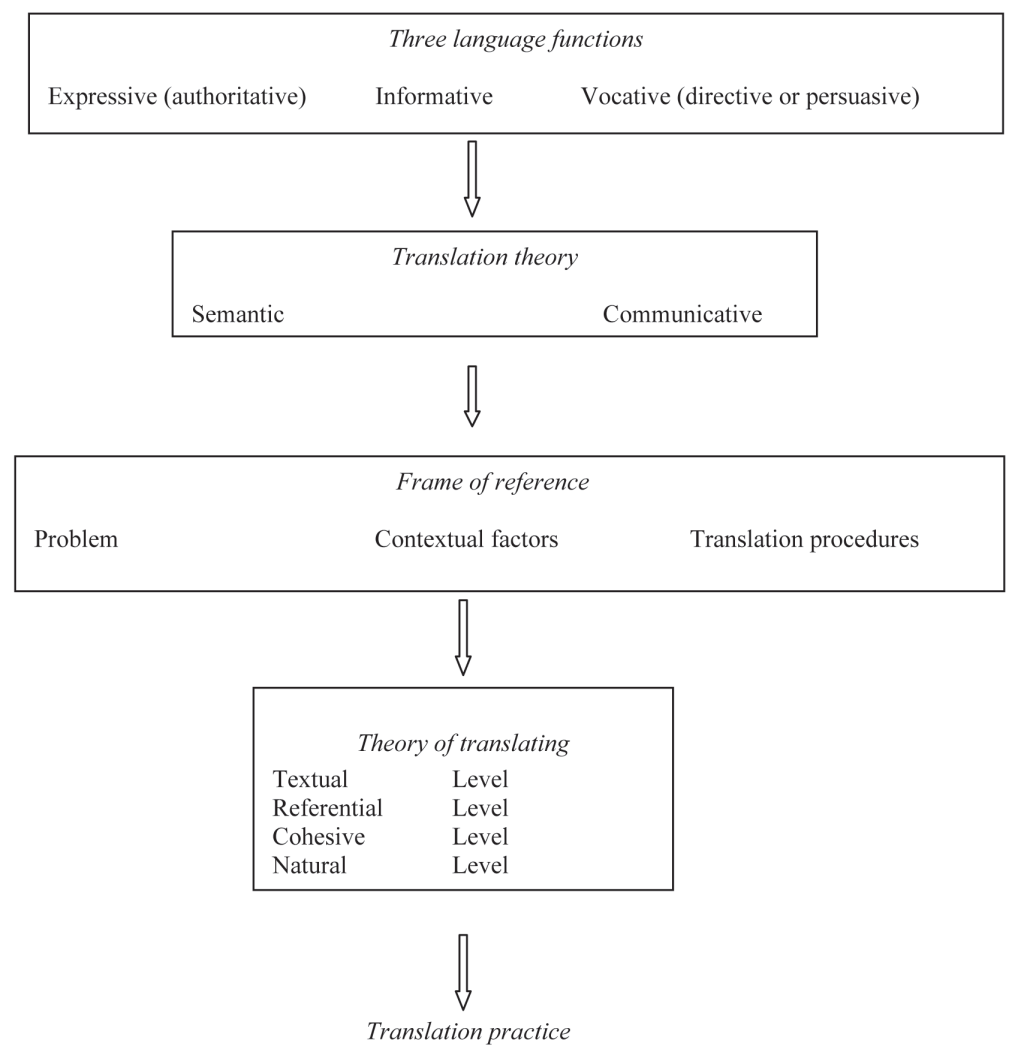

From this schematic representation of Newmark's functional theory of language, one is able to understand that there are many compromises between the functional and pragmatic approaches to translating. Nothing is cut and dried and the translator always strives to present the best translation to the target readers. In this article, I am going to try to facilitate a sensitive translation of terms referring to the organs of reproduction, bearing in mind the sensitivity of the subject when applying these language functions.

Nord's (1997:45-46) model includes seven points:

- A 'pragmatic model', which accounts for communicative interaction etc.

- A 'culture-oriented model', which considers culture-specific behaviour.

- A 'consistent model', to establish a framework that is coherent and provide guidelines to justify the translator's decisions regarding any type of translation.

- A 'comprehensive model', which can be applied to all text types.

- An 'anti-universalist model', which allows for culture-specific differences.

- A 'practical model', accounting for all transcultural communication.

- An 'expert model', which awards translators the prestige of being competent and responsible experts in their field.

Written texts always have an audience in mind who, according to Nord (2000:198), should be the most important standard influencing the writer. The audience is distinguished as the receivers of a translation and those persons who are the actual readers or listeners of the text. At the same time, this audience also belongs to a type of person to whom the text is addressed, and who are the addressees. Translators, who are genuine receivers of the source text, are generally not the addressees, but they belong to the target culture in question, in this instance, Northern Sotho. 
For many years, and still today, the translation of the organs of reproduction (biological terms) into Northern Sotho and any other African language is influenced by how the target readers would receive them. This means that in most cases, it is expected of the translator to translate the document in such a manner that it conforms to the receptor culture. This type of approach does not consider the content of the document and the message embedded in it, but the need to produce a document that is culturally attuned to the target reader without necessarily communicating a message to him/her. Emphasis is placed solely on the preservation of moral convictions and not on the conveyance of information to the readership. This results in conflict between cultural adaptation and effective communication. In order for one to translate these terms, one has to refer to Newmark's eight proposed possible translation methods (1988:45):

Table 1: Newmark's eight proposed possible translation methods (1988:45)

\begin{tabular}{|l|l|}
\hline Source language emphasis & Target language emphasis \\
\hline Word-for-word translation & Adaptation \\
\hline Literal translation & Free translation \\
\hline Faithful translation & Idiomatic translation \\
\hline Semantic translation & Communicative translation \\
\hline
\end{tabular}

In this article, the use of two types of translation method will be discussed that is, an idiomatic and a communicative method. These methods were chosen in order to address the problem of cultural limitations.

Newmark (1988:47) defines idiomatic translation as the translation that produces the message of the source text but tends to distort the nuances of meaning by preferring colloquialism and idioms where these do not exist in the original text. That is why Dusse (1995) perceives this method as an artful deviation from ordinary and familiar words. In this context, one may agree with Dusse (1995) who claims that idiomatic translation pays full attention to the artistic qualities of the text, which serves aesthetic purposes, without taking into consideration the information content of the text. Idiomatic translation emphasizes the pleasure and the delight of the reader of the translated text at the expense of the communicative interaction. It can be said that the emphasis is on appeasement rather than satisfaction.

On the other hand, the communicative translation method, as the term suggests, focuses on the language as a vehicle for conveying information. According to Newmark, this type of translation method attempts to render the exact contextual meaning of the original in such a way that both the content and language are readily acceptable and intelligible to the readers (1988:47). It could be said that this type of translation is functionally equivalent to the original in as many of its dimensions as possible. The communicative translation method concerns itself with the manipulation of the linguistic system by the translator to encode a particular message. This type of translation accounts for how language is used as a means of encoding the speaker's intended message. One of its most striking characteristics is that it is preoccupied with what should be said rather than how it should be said. The 'what' in this context refers to the content or the subject matter and the 'how' refers to the manner of presenting the subject matter. It seeks to make information more accessible to the reader, taking into account the different cultural backgrounds of the two texts.

One might mention a few of Newmark's (1982:128-129) rules of translation that a translator should follow or guard against when translating. They are the following:

- Translation is for the reader. Normally translation is written and intended for a target reader even when the source text was not written for a particular reader but for fun, for example, how Harry Potter's author started scribbling (writing) her first book in a restaurant while waiting for her orders. 
- The naturalness of a translation. It is important for the translator to write within his/her own idiolect so that the text should appear to be written naturally.

- The frequency rule again. This has to do with equivalency. It is important for the translator to use a word that is more effective at his/her disposal even though the source language did not use that word.

- The importance of the truth. It is more appropriate for the translator to correct or gloss any misstatements, as they will affect the quality or the interpretation of the translated text. This rule is mostly an informative function.

- The limits of synonymy. Although translation uses synonymy, it should not be used indiscriminately to avoid a habit of replacing accurate equivalents with synonyms. It is important for the translator to guard against interferences of synonyms especially if the text is informative.

\section{Translating culturally sensitive concepts}

The issue of how to translate culturally sensitive concepts has proved to be controversial, especially with respect to organs of reproduction and their function (biological terms). It is unlikely that one would find a translated biology text book dealing with organs of reproduction although due to the HIV/Aids pandemic, certain materials regarding HIV/Aids education are being translated into various African languages, including Northern Sotho.

During the process of translating these HIV/Aids materials, euphemism plays an important role, thus resulting in loss of the actual meaning in some instances. Organs of reproduction, such as genitals and sexual intercourse and their function, are unlikely to be found easily in Northern Sotho text books, especially where their equivalents are used literally. These are regarded as strong taboo, as they are associated with sex and the so-called private parts of the body. It is easy to name the organs of reproduction in English without the reader feeling offended, even if the reader is a Northern Sotho speaker, but immediately one names the very same parts in Northern Sotho, the reader feels offended or switches off. This is the dilemma that a translator of biological sciences is faced with.

The use of metaphorical expressions does not deliver the intended message in many cases. The following examples will be used in an attempt to overcome the lack of equivalence or to be culturally sensitive when translating the terms of organs of reproduction. This list will highlight some of the problems that I encountered while translating HIV/Aids material for the Department of Health and other non-governmental organizations such as Soul City. I have translated them literally and figuratively into Northern Sotho:

Table 2: Taboo terms or culturally sensitive terms

\begin{tabular}{|l|l|l|l|}
\hline Concepts & Figurative translation & Literal translation & Dictionary definitions \\
\hline Abortion & Go senya mpa & Go ntšha mpa & $\begin{array}{l}\text { The termination of pregnancy either } \\
\text { legally or illegally. }\end{array}$ \\
\hline Anal sex/intercourse & Matanyola & $\begin{array}{l}\text { Having sex through the rectum or } \\
\text { anus/inserting the penis or sex toy } \\
\text { into the rectum or anus. }\end{array}$ \\
\hline Anus & $\begin{array}{l}\text { Anase/setho sa go ithoma/ setho } \\
\text { sa go ntšha makaka }\end{array}$ & Mogwete/motete & $\begin{array}{l}\text { The opening in a person's bottom } \\
\text { through which solid waste leaves } \\
\text { the body. }\end{array}$ \\
\hline Bladder & Setho sa go swara moroto & Senya/sebudula & $\begin{array}{l}\text { Membranous bag in human and } \\
\text { other animal bodies. }\end{array}$ \\
\hline Faeces/excrement & Mantle/makaka & $\begin{array}{l}\text { Solid waste material that leaves the } \\
\text { body through the anus. }\end{array}$ & $\begin{array}{l}\text { External or internal body parts of a } \\
\text { man or woman that have to do with } \\
\text { sex. }\end{array}$ \\
\hline Genitals/private parts & Ditho tša thobalano & Mapele & $\begin{array}{l}\text { A natural flow of blood from the } \\
\text { womb, usually once a month. }\end{array}$ \\
\hline Menstruation & Go bona kgwedi/go hlapa & $\begin{array}{l}\text { Tšhologo ya madi ya tlhago } \\
\text { go tšwa popelong kgwedi ka } \\
\text { kgwedi }\end{array}$ & \\
\hline
\end{tabular}




\begin{tabular}{|c|c|c|c|}
\hline Penis & Setho sa bonna/morotwana & Lepele/ntoto & $\begin{array}{l}\text { Part of the man's body used for } \\
\text { urinating and for having sex. }\end{array}$ \\
\hline Placenta & $\begin{array}{l}\text { Kobo ya ngwana yo a sešogo a } \\
\text { belegwa }\end{array}$ & Mohlana/samorago & $\begin{array}{l}\text { The material that comes out of a } \\
\text { woman or female animal's body } \\
\text { after a baby is born, and which was } \\
\text { necessary to feed and protect the } \\
\text { baby. }\end{array}$ \\
\hline Sexual intercourse & Go robalana/go tsena lepaing & Go nyobana & $\begin{array}{l}\text { An activity involving the penetration } \\
\text { of a penis into the vagina or anus. }\end{array}$ \\
\hline Sperm/semen & Peu/seela sa bonna & Matšhedi/disepeme & $\begin{array}{l}\text { A cell that is produced by the sex } \\
\text { organs of a male that can combine } \\
\text { with a female egg to produce young. } \\
\text { A liquid which is produced by the } \\
\text { male sex organs that contains these } \\
\text { cells - semen. }\end{array}$ \\
\hline Testicles & $\begin{array}{l}\text { Setho sa bonna sa go tšweletša } \\
\text { peu ya bonna }\end{array}$ & Marete & $\begin{array}{l}\text { Organs that produce sperm, enclosed } \\
\text { in a bag of skin below the penis. }\end{array}$ \\
\hline To defecate & $\begin{array}{l}\text { Go ithoma dikgapana/go ya } \\
\text { sethokgweng }\end{array}$ & Go nya/go ntšha masepa & $\begin{array}{l}\text { To get rid of the undigested waste } \\
\text { food through the anus. }\end{array}$ \\
\hline Uretha & $\begin{array}{l}\text { Mothapo wa mohlapologo/ mo } \\
\text { go banna go elela gape le seela } \\
\text { sa bonna/ yuretha }\end{array}$ & $\begin{array}{l}\text { Tšhupu ya moroto le matšhedi } \\
\text { goba disepeme }\end{array}$ & $\begin{array}{l}\text { The tube that carries liquid waste } \\
\text { out of the body in men and male } \\
\text { animals. Sperm also flows along } \\
\text { this tube. }\end{array}$ \\
\hline Urine & Mohlapologo & Moroto & $\begin{array}{l}\text { Waste liquid that collects in the } \\
\text { bladder and is passed from the body } \\
\text { through the urinary tract. Pale- } \\
\text { yellow fluid secreted from the blood } \\
\text { by the kidneys, stored in the bladder } \\
\text { and discharged through the uretha. }\end{array}$ \\
\hline Uterus & $\begin{array}{l}\text { Setho sa bosadi seo ngwana a } \\
\text { golelago ka go sona }\end{array}$ & Popelo & $\begin{array}{l}\text { The organ in women and female } \\
\text { animals in which babies develop } \\
\text { before they are born. }\end{array}$ \\
\hline Vagina & Setho sa bosadi & Nnyo & $\begin{array}{l}\text { Sheath-like covering; sexual passage } \\
\text { in female from the uterus to the } \\
\text { external orifice. }\end{array}$ \\
\hline
\end{tabular}

Ingstad (1990) shares the same views by stating that figures of speech, especially in scientific texts, are misleading because they state a supposition rather than a fact. His research report, which looks at the function of metaphor in science and scientific texts, bears testimony to these claims. In the report, he discusses what roles, if any, metaphors may play in constructing science and scientific texts. He noted that the meaning of the same metaphorical expression does not necessarily remain constant. He further argues that metaphors do not feature in scientific texts because when people speak in metaphors, messages often get misunderstood. In medical text, the facts are vital and must be persuasively presented in ordinary language in order to transmit the intended message.

Gibbs (1994:121) also affirms this view by saying that scientific texts are not concerned about the richness of linguistic devices and figurative manifestations. He writes that 'literal meanings are proper, metaphorical language is distorted and deviant'. Metaphors, in his opinion, require a special talent or genius, which is alien to most ordinary people (1994:121). Speakers should avoid using metaphors at all costs when their conversation deals with essential issues, especially those that could cause physical and emotional damage to the life of an individual when misunderstood. Factual and accurate information is a necessity in such contexts, to satisfy the target audience.

One notes from these viewpoints that figurative language is inaccessible to many of the youth in particular. It distorts the intended and real message. The officiousness and parabolic nature of language in general, but specifically in taboo language, is experienced as ridiculous and often deflects attention from the real issue that the youth have to grapple with. There is no need for speakers to use complex vocabulary, which possesses specific connotations. It is imperative for those engaged in a communicative interaction to transform language in such a manner that it is 
readily accessible and understandable. Translators should be encouraged to use conventional, obvious and general words in the interest of clarity and simplicity.

\section{Translation of taboo terms}

The general public and the translators' are divided on the way in which the taboo terms should be translated. There are two conflicting views. The one prioritizes cultural sensitivity in translation whereas the other is messageoriented. The former argues that translation cannot be fully understood outside a cultural frame of reference. In other words, translators should serve as cultural mediators. This implies preserving the cultural norms and rules in the target language. Cultural preservation has a lot to do with the suppressing of the individual's freedom of expression. Due to certain social influences translators are unable to translate accurately.

This cultural preservation has to do with suppressing the individual's freedom of expression. It is continuously undermining the individual's constitutional rights as enshrined in the Bill of Rights, outlined in section 2 subsection 30 of the South African Constitution. The South African Constitution provides for the development and promotion of the equal use and enjoyment of all the official languages of South Africa. In this sense, the concepts of 'development' and 'promotion' mean that the African languages, which were sadly neglected and disadvantaged, deserve recognition. This development, and the promotion of the equal use and enjoyment of all the official languages of South Africa, refers not only to their technical development, but also to legalizing those terms that are forbidden; in this context, the organs of reproduction (biological science). The following are examples of the so-called taboo words collected from biology textbooks and health material that I have translated figuratively and literally into Northern Sotho: anus, genitals/private parts, menstruation, penis, placenta, sexual intercourse, testicles, to defecate and vagina (cf. Table 2).

In translating these biological terms, the translator had to choose the words or phrases carefully, so as not to offend the target readers, in this instance Northern Sotho speakers. For the translation to be acceptable by the target readers, it has to be borne in mind that figurative rather than literal translation will make the targeted readers more comfortable. Words in literal translations are the equivalents of the source words (biological terms), but they are culturally offensive and prohibitive to the target reader.

Dr B.S. Ngubane, the former South African Minister of Arts, Culture, Science and Technology, in his opening address to the second in a series of language planning workshops involving language specialists that his department conducted, stressed the need to 'overcome our barriers of language prejudice in order to make a significant contribution to the transformation of our society' (1997:1). He articulated the view that an extensive transformation of our society will unquestionably fail if we do not recognize language as an essential resource in improving the quality of life of our people (1997:2).

Ngubane's (1997:8) perception of language as an 'important instrument in nation-building' is similar to that of Mey (1985:328), who sees language as being at home in a society-on-the-move, using language as a revolutionary activity. Both these options imply that language should be used as an instrument to develop and empower society. By sharing information with one another through language, people will draw from these informal discourses the knowledge necessary to confront the challenges ahead. Translators are experiencing what could be termed linguistic resources with their readers because certain expressions may be distasteful to the latter. Their ultimate humiliation is to accept without questioning the so-called non-offensive strategies that are to be employed in communicative interaction. This subsequently results in communication breakdown.

Ngubane takes the argument a step further and emphasizes the need to create a climate of language tolerance. He also advocates a change in strategy, using more efficient and cost-effective communication. This implies consciously working to overcome the communication barriers by replacing idiomatic phrases with factual, easily 
understood information. He warns that 'our ignorance will be our downfall and we will ultimately fail those we are meant to serve' (1997:8).

The philosophy of sociolinguistics calls for the preservation of cultural prerequisites in translation. The sociolinguistics scholars argue that language is not only a vehicle for expressing ideas and intentions. Deep, at the root of ordinary words, lie the attitudes, values, aspirations, expectations, social rules and the sensitivities of people. Most sociolinguists argue that any translation that ignores cultural conventions is bound to fail. The failure of the translator's ignorance of cultural conventions, as argued by most sociolinguists, will depend on the intended message as well as the context under which the intended message is transmitted.

A message-oriented approach, which is contrary to a cultural approach, acknowledges the relevance of cultural complications but not at the expense of effective communication. Effective communication, in this context, implies the total accuracy and transparency of information. Translation approaches should be based on linguistic orientation rather than cultural transfer.

McDonald (1996) argues that as long as people arrive at a consensus, they are at liberty to select their own taboos. For instance, if readers agree that the word 'apartheid' be regarded as taboo, then it would be. If this is the case, then one may ask if it is possible to remove all the negative meanings attached to the terms used for the organs of reproduction (biological science) to enable translators to translate health material or biological terms, such as sexual intercourse, freely.

\section{Conclusion}

The above discussion has highlighted the fact that language cannot be completely removed from culture, hence it is through language that human beings proclaim their cultural identities. It can be said that cultural barriers will always prohibit the translator from translating reproduction terms in their original form or equivalence. Society, including the translator, has to constantly rename and repackage the euphemistic words to make them sound better to fit a new order of society. The translator will constantly resort to circumlocutions and euphemisms to avoid directly mentioning matters pertaining to parts of the body, bodily functions, sex, and so on. Certain thoughts that are too deep for words are taken care of by not expressing them at all. Each social group is unique in how it constrains linguistic behaviour. Perhaps one linguistic universal is that no social group uses language totally without constraints.

\section{References}

Alberts, M. 1997. 'Legalese, South Africa's 12th official language?' Paper read at the First Seminar of the Northern Province Language Council (NPLC), Pietersburg.

Bassnett-McGuire, S. 1980. Translation studies. London: Routledge.

Dusse, C. 1995. The metaphors in Song of Songs and adolescents: A reception-theoretical investigation and proposed translation. Unpublished PhD thesis. Potchefstroom: University of Potchefstroom.

Fowler, R. 1993. A dictionary of modern critical terms. London: Routledge.

Fromkin, V. \& Rodman, R. 1993. An introduction to language. London: Harcourt Brace College Publishers Gibbs, R.W. 1994. The poetics of mind, figurative thought, language and understanding. New York: Phoenix. Goodenough, W.H. 1964. Cultural anthropology and linguistics. New York: Harper \& Row.

Hermans, T. 1996. Norms and the determination of translation. A theoretical framework, in Translation, power, subversion, edited by R. Alvares \& M. Carmen Africa. Great Britain: WBC Book Manufacturers Ltd.:32-34.

Ingstad, B. 1990. The cultural construction of AIDS and its consequences for prevention in Botswana. Medical Anthropology Quarterly 4(1):28-40.

National Terminology Services. 1997. The feasibility of technical language development in the African languages. Pretoria: DACST. 
Newmark, P. 1982. Approaches to translation. England: Pergamon.

Newmark, P. 1988. A textbook of translation. New York: Phoenix.

Ngubane, B.S. 1997. Opening address for workshops, in The feasibility of technical language development in the African languages. Pretoria: National Terminology Services. DACST:1-8.

Nida, E. 1964. Towards a science of translating. Leiden: E.J. Brill.

Nord, C. 1997. A functional typology of translations, in Text typology and translation, edited by A. Trosborg. Amsterdam: John Benjamins:43-66.

Nord, C. 2000. What do we know about the target-text receiver?, in Investigating translation, edited by A. Beeby, D. Ensinger \& M. Presas. Amsterdam: John Benjamins:195-212.

The Constitution of South Africa, 1996. Pretoria: Government Printers.

Wardhaugh, R. 1992. An introduction to sociolinguistcs. Oxford: Blackwell.

Wilss, W. 1996. Knowledge and skills in translator behaviour. Philadelphia: John Benjamins. 